\title{
SIMULATED GLACIAL ABRASION
}

\author{
By W. H. Mathews \\ (Department of Geological Sciences, University of British Columbia, Vancouver, British \\ Columbia V6 $\mathrm{T}_{\mathrm{I}} \mathrm{W}_{5}$, Canada)
}

\begin{abstract}
Glacial abrasion has been simulated by turning a grindstone made of ice and crushed quartz between two stone plates within a domestic deep-freeze. Within limits, the speed of rotation, the normal loading, and the temperature of operation can be controlled. The tangential force exerted on one of the stone plates can be measured. The ratio of tangential to normal force, the effective coefficient of friction, is found to vary with the "roughness" of the grindstone, to increase gradually as abrasion proceeds, and to increase with decreasing velocity. Even at very low temperatures (to $-26^{\circ} \mathrm{C}$ ), abrasion products accumulated in a pad of ice frozen to the tablet "down-stream" from the grindstone, indicating that a water phase at least momentarily exists. The abraded surface of a fine-grained limestone displays grain-from-grain plucking dominating over abrasion of individual crystals. The abraded surface of a granite, by contrast, shows striations of crystals and rupture of cleavage along individual striae.
\end{abstract}

RÉsumé. Simulation de l'érosion glaciaire. L'érosion glaciaire a été simuléc en faisant tourner une meule faite de glace et de quartz pilé entre deux pierres plates à l'intérieur d'un congélateur domestique. Entre certaines limites, la vitesse de rotation, la charge normale et la température de l'opération peuvent être controlées. On peut mesurer la force tangentielle exercéc sur l'une des pierres. Le rapport des forces normales et tangentielles, le coefficient effectif de frottement, a été trouvé varier avec la "rugosité" de la meule, croitre graduellement quand l'abrasion se développe et croitre si la vitesse diminue. Même à des températures très basses (jusqu'à -26 C) l'accumulation des produits de l'abrasion dans un coussin gelé sur la plateforme support à "l'aval" de la meule, montre qu'une phase aqueuse existe au moins momentanément. La surface abrasée d'un calcairc à grain fin manifeste un arrachement grain-par-grain l'emportant sur l'usure des cristaux individucls. La surface abrasée d'un granit, au contraire, présente des striations des cristaux individuels et des ruptures de failles le long de chaque strie.

Zusammenfassung. Simulation der glazialen Abrasion. Glaziale Abrasion wurde durch Drchen eines Mühlsteines aus Eis und zerstossenem Quarz zwischen zwei Steinplatten in einer Tief kühltruhe simuliert. Die Drehgeschwindigkeit, die Normallast und die Versuchstemperatur kann innerhalb gewisser Grenzen reguliert werden. Die Tangentialkraft, die auf eine der Steinplatten wirkt, lässt sich messen. Das Verhältnis der Tangential- zur Normalkraft, der effektive Reibungskocffizient, erweist sich als variabel mit der "Rauhigkeit" des Mühlsteins; er wächst mit fortschreitender Abrasion allmählich an und nimmt mit abnehmender Geschwindigkeit zu. Selbst bei sehr niedrigen Temperaturen (bis $-26^{\circ} \mathrm{C}$ ) sammeln sich Abrasionsprodukte in einem Eisblock, der an die Tafel "stromabwärts" vom Mühlstein anfriert, - ein Beweis dafür, dass zumindest momentan flüssiges Wasser auftritt. Die abradierte Oberfläche eines feinkörnigen Kalksteins lässt erkennen, dass Auslösung Korn für Korn weit häufiger vorkommt als die Abrasion einzelner Kristalle. Dagegen zeigt die abradierte Oberfläche cines Granits eine Riefung von Kristallen und Spaltbrüche längs einzelner Riefen.

\section{INTRODUGTION}

The problems of investigating subglacial erosion in the field are manifold; only very limited parts of the bed of a glacier are accessible and then commonly only for short periods (Kamb and LaChapelle, I964; Vivian, 1970; Vivian and Bocquet, I973; Boulton, [ ${ }^{\mathrm{C}}{ }_{1974}$ ]). To understand the process of glacial abrasion better, it seems profitable to examine some of the mechanisms in the laboratory where the effects of changing conditions might be explored one step at a time. To this end the writer conceived and the technical staff of his department assembled equipment to meet the following conditions:

(1) Abrasion by a mixture of rock chips embedded in an ice matrix, moving over (2) samples of rock, at (3) known and adjustable loading, (4) known and adjustable speeds, and (5) known and adjustable temperature.

The equipment (Fig. I) is designed to rotate an abrasive cylinder or "grindstone" at slow speeds between two stationary stone tablets. The grindstone is prepared by packing a mixture of crushed rock, or quartz, and granulated ice, or snow, around a hub set axially in a cylindrical mould, flooding the mixture with water, and freezing. When extracted from the mould, the grindstone is mounted, axis horizontal, in a linkage which permits, within limits, free vertical movement of the grindstone but prevents its horizontal displacement. Thus, as the 


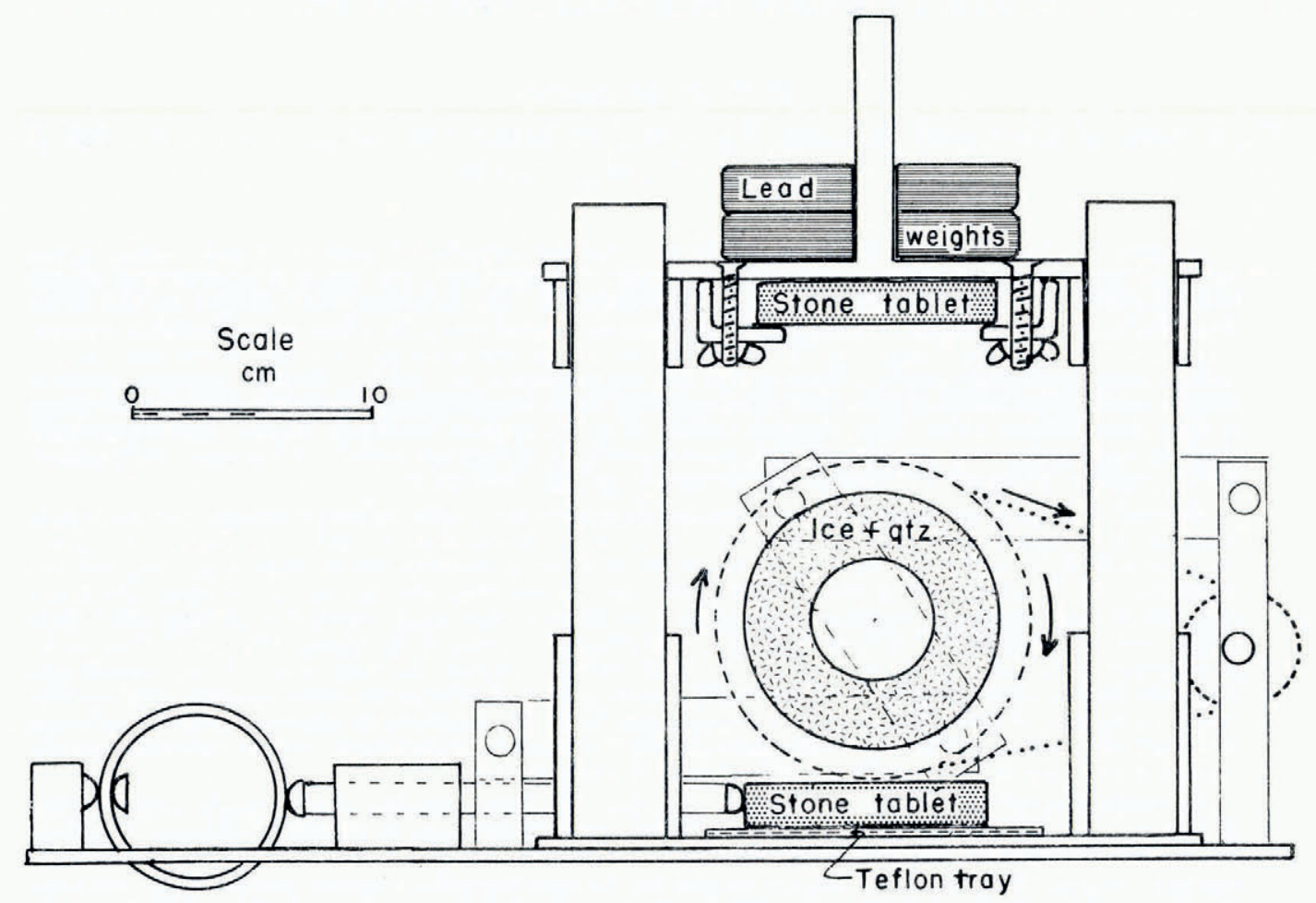

Fig. I. Longitudinal section of equipment for simulated glacial abrasion.

grindstone wears its way into the underlying stone tablet or loses diameter by abrasion, it can move downward and maintain contact with the tablet. Torque is applied to the grindstone by means of a chain drive and sprocket.

The lower of the two stone tablets rests within a "Teflon"-coated tray and bears against a proving ring with a strain gauge. The latter permits measurement of the tangential force exerted by the rotating grindstone. The upper tablet is clamped to a frame which is free to move vertically downward along two posts so that again contact can be maintained with the grindstone as wear continues. Dead weights can be added to the frame to increase at will the normal (vertical) loading between tablets and grindstone.

Motive power is provided by a $\frac{1}{4} \mathrm{~kW}$ electric motor via a Zeromax JK variable-speed impulse drive and a chain and gear assembly to the grindstone. The variable-speed drive provides a starting torque of about $\mathrm{I} 0 \mathrm{Nm}$ at low operating speeds and a substantially higher torque when set for higher speeds. For most of the early tests the output of the variable-speed drive was set at about 9 r.p.m., equivalent to 1 r.p.m. at the grindstone and an effective movement of its periphery of $34 \mathrm{~cm} / \mathrm{min}$.

The equipment operates within a commercially manufactured domestic deep-freeze cabinet capable of operating at temperatures between -16 and $-26^{\circ} \mathrm{C}$. A few tests have been run at higher temperatures by turning off the refrigerator and allowing the contents to warm slowly. A commercial temperature controller (Y.S. I Model 74) has since been installed to maintain constant temperatures between $-10^{\circ} \mathrm{C}$ and zero.

The equipment as assembled has proven to be a very useful exploratory tool but certain limitations can be noted: 
I. It has not proven possible to obtain complete uniformity in the grindstone. Tangential force and abrasion vary somewhat during a full revolution of the grindstone.

2. Velocities of the grindstone surface of $0.3 \mathrm{~m} / \mathrm{min}$ are unrealistically high for basal glacier flow but are dictated in part by the desire to produce visible changes in hours rather than in years. Much slower speeds can be introduced, if required, by a change in gear ratios.

3. The temperatures of operation, -16 to $-26^{\circ} \mathrm{C}$, are unrealistically low for most glaciers, even though they offer protection of the grindstone against destruction by melting.

4. Stress, both normal and tangential, is difficult to measure directly as both are a function of contact area between grindstone and tablet. The contact area can be estimated at any time by measuring the area of the groove abraded in the tablet but this involves stopping the motor and withdrawing the tablet. Moreover, because the lower tablet and the proving ring which supports it are displaced slightly as the tangential force increases, the width of the groove may not be a true measure of the instantaneous contact area. Finally, because of the roughness of the grindstone surface, only a part of the groove may at any one instant be carrying the load imposed upon it.

5. Measurement of the amount of wear has proven to be much more difficult than anticipated. Depth, width, and length of striations scored in the tablet surface are all highly variable. No consistent measure of volume worn away has been obtained either by weighing tablets before and after a test or by measuring the amount of a powder needed to fill the abraded groove to the original surface. A calculated value, based on the average length of the striae and the assumption that their longitudinal profile is the arc of a circle, provides the best measure of wear.

\section{Results}

For most of the tests undertaken to date the tablets have been made from a fine-grained homogeneous high-grade limestone of Triassic age from Texada Island, British Columbia. The grindstone has been prepared using crushed quartz sieved to pass a $2 \mathrm{~mm}$ screen as the abrasive, making up $15^{-20} \%$ by weight of the ice-quartz mixture. The grindstone has been operated at a peripheral velocity of $30-50 \mathrm{~cm} / \mathrm{min}$ for periods of $\frac{1}{2}-2 \mathrm{~h}$. Normal loads have varied from 8 to $3 \mathrm{I} \mathrm{kg}$, and temperatures from -26 to about $-5^{\circ} \mathrm{C}$.

One of the first observations to be made in a test is that of a cyclic pattern in the tangential force exerted as "rough" and "smooth" patches on the grindstone pass over the tablet during each rotation. This is most notable at slow speeds of rotation during which fluctuations of commonly $15 \%$ above and below a mean value and when, on rare occasions the grindstone has been brought to a full halt with as much as a four-fold increase in tangential force. The rough patches are expressed not only by the increase in force and slowing of the drive but also by a marked increase in audible grating or grinding noise.

In any one test, other factors remaining constant, the ratio of tangential to normal force, the effective coefficient of friction, decreases with increasing velocity. Tangential force can reach $15 \mathrm{~kg}$ under vertical loading of $22 \mathrm{~kg}$ at speeds of $4 \mathrm{~cm} / \mathrm{min}$, whereas at a speed of $200 \mathrm{~cm} / \mathrm{min}$ it may not exceed $10 \mathrm{~kg}$.

The effect of temperature is not clearly defined; many but not all tests undertaken at low temperatures have higher coefficients of friction than those at $-10^{\circ} \mathrm{C}$ or warmer. Even at $-26^{\circ} \mathrm{C}$, however, it is evident that a liquid water phase can locally be developed only to refreeze as an icy pad on the tablet on the lee side of the contact area.

Abrasion products are accumulated in this icy pad. Typical examples are composed of $75-85 \%$ by weight of ice and only $15-25 \%$ of rock fragments, both limestone powder (in the case of the limestone tablets) and quartz grains ripped from the grindstone. 


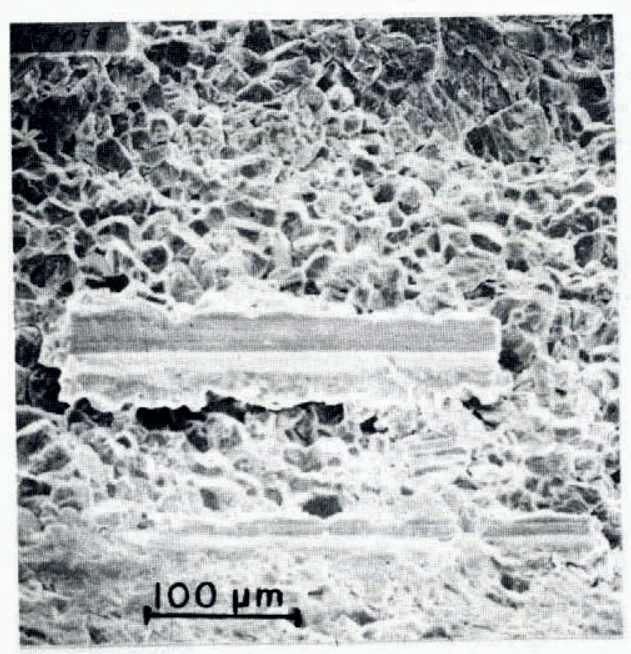

a

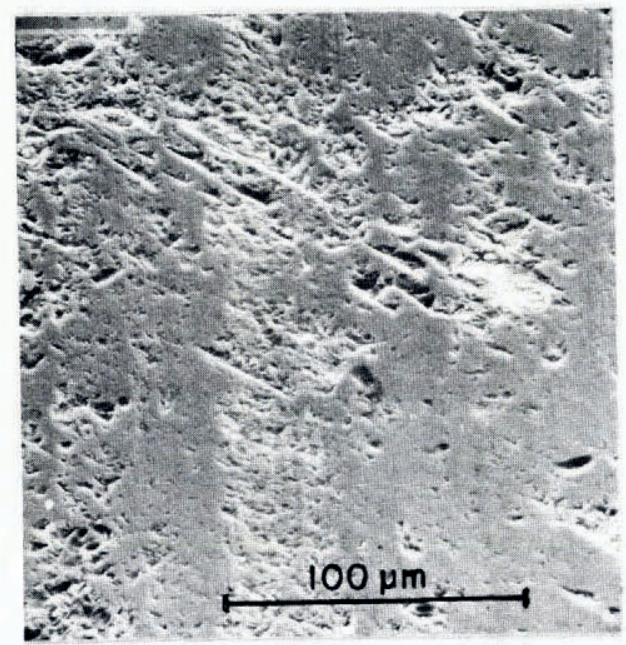

c

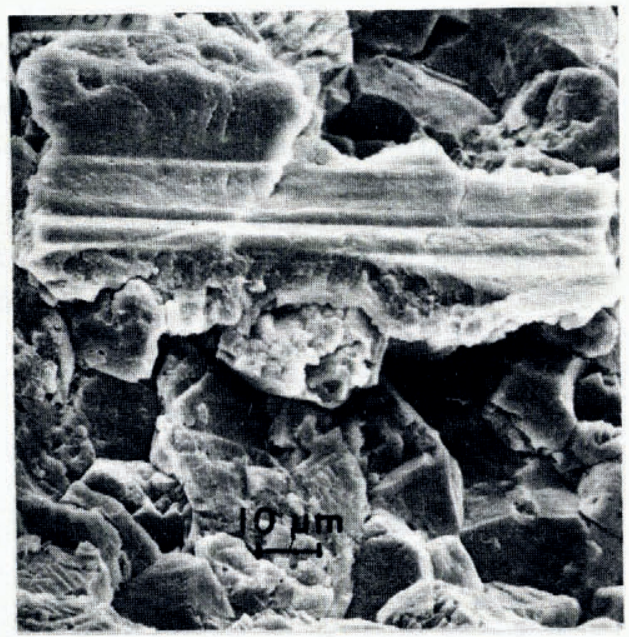

b

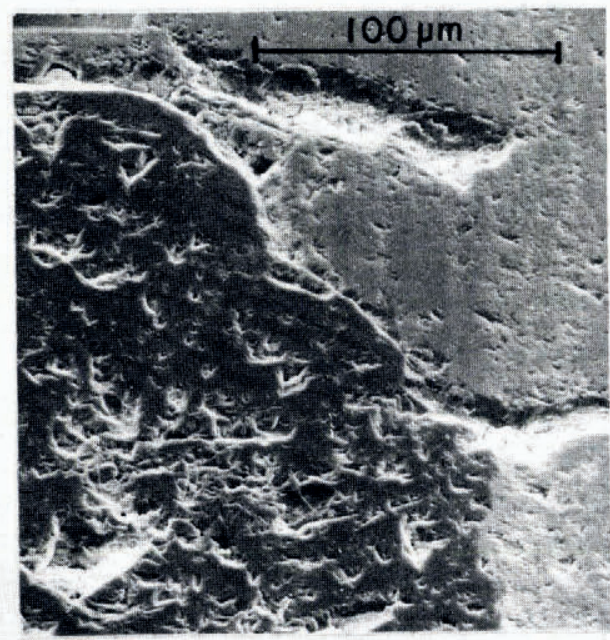

d

Fïg. a Striated and plucked surface of fine crystalline limestone. (b) Details of striated and plucked surface of fine crystalline limestone. (c) Striated surface of a feldspar crystal in granite showing cleavage. (d) Quartz grain (lower left) standing in relief above an abraded surface of feldspar in granite.

An examination of the abraded surface of a limestone tablet with the scanning electron microscope shows that only a small part is striated and that a much greater area has been subject to plucking of grain from grain (Fig. 2a and b). By contrast, a sample of granite, which proved to be much more resistant to wear, shows striated bands in which minute cleavage fragments had been torn from the feldspar (Fig. $2 \mathrm{c}$ and $\mathrm{d}$ ).

\section{Discussion}

Insofar as any point on the surface of the rotating grindstone is concerned, it may duplicate only momentarily the conditions at the base of the glacier. The high normal stress briefly applied is followed after a few millimetres of additional motion by an environment with one 
atmosphere pressure. By the same token, the icy matrix briefly experiences pressure melting, judging from the pad of ice developed on the tablets, then emerges into an environment where the air temperature is typically -16 to $-26^{\circ} \mathrm{C}$. Notwithstanding the drastic changes experienced in the simulation, they may still reproduce the variation in load and the alternation of thawing and freezing that commonly apply when basal ice passes over a rough bedrock surface.

The inhomogeneity of the grindstone, though offering a problem in obtaining uniform and reproducible results, is, however, manifestly similar to conditions in basal glacial ice.

Rate of expenditure of energy at the contact area between grindstone and tablet can be calculated from the measured tangential force on the tablet and the velocity of the grindstone surface. In one test this was found to be $2.8 \mathrm{~W}$ at 5.5 r.p.m. (peripheral velocity $187 \mathrm{~cm} / \mathrm{min}$ ), falling to $0.4 \mathrm{~W}$ at 0.55 r.p.m. and an estimated $0.08 \mathrm{~W}$ at $0.1 \mathrm{I}$ r.p.m. $(3.75 \mathrm{~cm} / \mathrm{min})$. Part of this energy is expended in plucking or scratching, but in all probability a much greater fraction is converted to heat. It is possible that this heat produces minor amounts of water which, transferred to the lee side of the contact area, refreeze and cement to the tablet the abrasion products, any fragments of abrasive, and possibly some granulated ice. Though the basis on which "comminution till" has been defined (Elson, I $96 \mathrm{I}$ ) appears to be misleading, in that comminution does not release energy for melting, the energy expended in overcoming friction may be partitioned between (I) mechanical abrasion or comminution and (2) provision of heat which in turn may release rock particles from the ice.

The rise in apparent coefficient of friction with decreasing velocity may be a significant factor if continued into the range of velocity applying at the base of a glacier. A slowing of ice movement related to the termination of a surge, to the passage of ice into a zone of compressive flow, or associated with a drop of pore pressure in the substratum, may lead to further increase in resistance to flow and perhaps to a cementing of the basal ice to its substratum. An associated drop in the rate of expenditure of energy at the bed may, moreover, permit refreezing and again favour the locking of the ice to its substratum.

The observations on the abraded surface of different rocks which have been subject to very similar conditions of abrasion, may prove helpful in understanding the mechanism of wear and in explaining the differences in resistance of the rocks in question. Thus, for example, relatively quick abrasion of the limestone tablets can be ascribed to the ease of plucking grain from grain, or to the breaking of relatively weak inter-crystal bonds linking calcite grains one to another. By contrast, the abrasion of feldspar involves, at least in part, the breaking of stronger intra-crystal bonds so as to free cleavage fragments, and quartz, stifl more strongly bonded and lacking cleavage, proves to be still more resistant.

\section{Acknowledgements}

Funds for the assembly of the equipment have been provided by Canada Department of Energy, Mines, and Resources through a research agreement. This is gratefully acknowledged. The contribution of Mr R. Rodway, technician for the Department of Geological Sciences at the University of British Columbia, in the detailed design, machining, and assembly of the equipment deserves special mention, as does the help given by Professor C. Brockley and Mr E. Jones of the Tribology Laboratory of the Department of Mechanical Engineering.

\section{REFERENCES}

Boulton, G. S. [ [ ${ }^{{ }^{1}}$ 1974.] Processes and patterns of glacial erosion. (In Coates, D. R., ed. Glacial geomorphology. Binghamton, N.Y., State University of New York, p. $4{ }^{1}-87$. (Publications in Geomorphology.)

Elson, J. A. r961. The geology of tills. Canada. National Research Council. Associate Committee on Soil and Snow Mechanics. Memoir 69, p. 5-36.

Kamb, W. B., and LaChapelle, E. R. 1964. Direct observation of the mechanism of glacier sliding over bedrock. fournal of Glaciology, Vol. 5, No. 38, p. $159-72$.

Vivian, R. A. 1970. Hydrologie et érosion sous-glaciaires. Revue de Géographie Alpine, Tom. 58, Fasc. 2, p. $241-64$.

Vivian, R. A., and Bocquet, G. 1973. Subglacial cavitation phenomena under the Glacier d'Argentière, Mont Blanc, France. Fournal of Glaciology, Vol. 12, No. 66, p. 439-51. 


\section{DISCUSSION}

G. S. Boulton: Because of the high rotation-rates required by your apparatus it is necessary to generate a shear stress five times larger than commonly found at the base of a glacier in order to break the adhesive bond between cold ice and rock. Do you believe that the features you have observed and the relationships you have established are applicable to glaciers?

W. H. Mathews: It remains to be established by many other tests under differing conditions whether and to what extent these results apply to glaciers. The objective of the experiment is to generate ideas to be tested in the field and not to replace the real glacier.

Boulton: The well-marked, smoothly striated tablets which you have observed on the surface of limestone in your experiments do not look, in my experience, like striae typically found on limestone surfaces. They do, however, look very like masses of comminuted rock flour which can be observed smeared on to the beds and adhering to them. They are well-packed and show the smooth pattern of striation you observed. Do you know that the striae are cut into intact limestone, and are not on the surface of secondarily aggregated masses of rock flour?

MATHEws: Your suggestion is a very real possibility.

B. HAllet: I have examined granites and limestones with the scanning electron microscope and found micro-structures in granite very similar to the ones in your experiments. For limestones, I have never seen any such conspicuous striae, hence the experiment may not be representative of the actual abrasion of limestone.

W. E. S. Henoch: Your laboratory experiments throw light on the formation of such forms as striae in nature. These features result from direct contact of debris embedded in the flowing ice with bedrock. Would you agree that such features as lunate fractures and crescentic gouges (which sometimes attain the size of 2-3 $\mathrm{m}$ and are considered by some to result from the abrasive power of glaciers) are formed by different forces? There is evidence to suggest that during glacier recession, due to changes in stress in glacier ice with embedded debris and in the temperature of glacier ice and bedrock, bedrock failure occurs which causes the formation of these features.

Mathews: I am not prepared to judge from the laboratory experiment so far carried out on the origin of lunate fractures and crescentic gouges, and I am doubtful if the equipment I have described could solve this point. 